\section{SOCKEYE FISHERIES}

The Sockeye Salmon Oncorhynchus nerka

By R. E. Focrster. (Fisheries Research Board of CanadaBulletin 162.) Pp. $x v+422$. (Queen's Printer: Ottawa, 1968.) $\$ 8$.

'THOUGH this book is mainly for the spccialist, there is much in it of interest to all biologists and conservationists. It is a thoroughly comprehensive study of a single species based mainly on the excellent researches of the author during the past forty ycars. In general the book is heavy reading; yet it has undisputed value as a book of reference, though regrettably it has no index. The detailed table of contents does not justify this omission.

Chapter one summarizes very competently the general life history of the sockeye, tagging methods and the "parent stream" theory. Tho history, utilization and exploitation of the sockeye fishery are the subjects of the sccond chapter, which ends with the warning that a high-scas or ocean fishery for the sockeye will adversely affect the stocks available for inshore fisheries. Fuerster deals expertly with the thorny problem of escapement; he quotes extensively from his own researches and stresses the need for escapement to continue throughout the fishing season so that all sections of the run be represented. $\mathrm{He}$ points out that there secms to be little correlation between escapernent and the numerical predietions of future runs. He then refers to the need for a great deal more work "on salmon production in any life history stage" in order to find out remedies which can be applied to reach maximum production. But he warns against the dangers of applying the results obtained from one region to another. I found it fascinating to read that cach stock of Sockeye salmon has inherited tho capacity and ability to store up sufficient reserves to enable it, under normal conditions, to get back to its natal stream area to reproduce. Thus the length of migration may be a racial characteristic, but the amount of reserve energy needed to overcome every unusual hazard is as yet unknown.

Upstream migration with its hazards, energy expenditure, mortalities, and their causes are dealt with in detail. I found the chapter on spawning behaviour of particular interest, though I regret the uso of the word "digging" and that no mention is rnade of the use and position of the fomale's ventral fin during bed preparation and the spawning act. I found fig. 16 confusing- hore the gravel removed by the activity of the female should be shown. In the Atlantic salmon this pile of gravel at the downstream end of the excavation plays an important part in eddy production. An excellent account is given of factors affecting the success of natural spawning.

The section on the lake residence of the young sockeye covers its distribution and feeding habits and leads on to environmental conditions in the waters studied. Again Foerster stresses the difficulty and dangers of comparing results from different regions and we are reminded that young sockeye may be "racially acclimated to different water conditions".

The contribution made to the nutrient salt supply of some sockeye waters by sockeye carcasses is said to be appreciablo and significant. The author wonders whether sufficient notice has been given to the relationship between the phosphate available and its dependence on the size of the escapement (or run). He suggests that because the sockcye runs are getting smaller the phosphate balance is affected and that this basic factor may limit productivity. Further study is recommended.

The place of the young sockeye in the lake community doals fully with the competitors and predators of the young fish in several lakes.

The production of different sockeye lakes based on the adequacy of the food supplies is of interest. As the author says-calculations cannot be too precise since the data on the quantity of plankton and number of sockeye are largely approximations. Nevertheless they may serve to indicate "general relationships". This they certainly do, and the whole chapter makes stimulating reading.

The seaward migration of the young sockeye from some lakes is said to follow the disappearance of the ice and an increased thyroid activity. It is suggested that sockeye salmon possess a built-in compass and chronomoter which help them find their way through lakes and probably help them home from the sea. They thus respond to "an inherited direction preference orien. tation", and the effect of this on transplanted stocks is discussed: details are given of large scale experiments already in progress on this topic.

A further full discussion on the efficiency of natural production is given with a reminder that the relationship between escapement and sea migration has been highly variable.

The comparatively recent work of the International North Pacific Salmon Commission on the distribution of sockeye in the North Pacific is reported in detail. Finally, the author deals relatively with serological and scale studies, management problems, artificial propagation and the possibilities of selective cross-breeding.

Generally the figures in the text are very good, but some of the photographs could have been larger.

J. W. JONES

\section{ANTARCTIC BIRDS}

\section{Antarctic Bird Studies}

Edited by Oliver L. Austin. (Antarctic Research Series, Vol. 12. Publication No. 1686.) Pp. ix +262 . (American Geophysical Union of the National Academy of Sciences National Research Council: Washington, DC, 1968.) $\$ 16.50$.

Sevmeral volumes in this series are devoted to biological subjects, and the present one consists of eight papers on birds. The senior author of one, Dr William J. L. Sladen, has boen a leader in first British and then American work in this field, and he sets the scene in his opening words: "Antaretica supports vast colonies of specially adapted, long-lived, polar sea birds that, bccauso of their tameness and easy accessibility, offer opportunities for research into population dynamics and social behaviour difficult to match elsewhere in the world". His paper, the last in the book, gives the results of the American bird-banding programme of 1958-65; but it also reviews Antarctic bird-banding activities in general, from their inception as early in the history of that method as 1909. In the programme under report, almost 100,000 birds of 35 species have been marked, special techniques being used (including flipper bands on penguins) to suit the ennditions. With penguins and the smaller petrels, for which romote recoverics are scarcely to be expected, the main aim has been population studies; the albatrosscs and the giant petrel, however, have yielded spectacular records of migration.

The first paper in the collection is on the biology of the great albatrosses (two Diomedea spp.); points espccially studied in $D$. exulans include the immensely long fledging period (averaging 278 days) and the related fact that the parents do not usually breed again in the following season. Five papers deal with aspects of the life of the Adelie penguin-territorial and social behaviour, circadian rhythms of activity, egg and serum proteins, salt and water metabolism and food preferences. The remaining paper differs in being a faunistic study of the birds of an island about one square kilometre in extent, where seven species were found nesting in numbers ranging from 63 to 35,000 .
LANDSBOROUGH THOMSON 